\title{
Chemical, enzymatic and physical characteristic of cloudy apple juices
}

\author{
Mirosława Teleszko ${ }^{1}$, Paulina Nowicka² \& Aneta Wojdyło² \\ ${ }^{1}$ Wroclaw University of Economics, Department of Equipment and Process Engineering, 53-345 Wroclaw, Poland, Komandorska \\ $118 / 120$ St. \\ ${ }^{2}$ Wrocław University of Environmental and Life Sciences, Department of Fruit and Vegetable Technology, 51- 630 Wroclaw, \\ Poland, Chełmonskiego 37 St. \\ e-mail: miroslawa.teleszko@ue.wroc.pl
}

\begin{abstract}
In this study cloudy juices from six apple cultivars: 'Alwa', 'Fiesta', 'Gloster', 'Golden Delicious', 'Mutsu' and 'Pinova' were characterized in respect of polyphenols content by UPLC, PME (pectin methylesterase) activity, color, viscosity, and stability of turbidity. Apple cultivar affected significantly the chemical, enzymatic and physical properties of juices. Total quantitated polyphenols ranged from $686.63 \mathrm{mg} \mathrm{l}^{-1}$ ('Gloster') to $988.63 \mathrm{mg} \mathrm{l}^{-1}$ ('Alwa'), and polymeric proanthocyanidins were a dominant group of these compounds. All of products contained also high content of phenolic acids, mainly chlorogenic. The thermal treatment of juices did not cause a complete inactivation of pectin methylesterase. Taking into account the $\%$ of residual enzyme activity, the pasteurization was more efficient in the case of 'Fiesta' and 'Pinova' juices (13\% and $14 \%$ of the initial activity, respectively). Examined juices were characterized by low values of a stable turbidity (18.07-37.75\%), despite relatively high viscosity (2.40-9.60 mPas).
\end{abstract}

Key words: apple, cloudy juice, polyphenols, pectin methylesterase, physical analysis

\section{Introduction}

Apples (Malus domestica Borkh.) are processed into a variety of products, mainly in the form of clear juice. In Europe it is a highly consumed product, second after orange juice (Kahle et al. 2005, Kay-Shuttleworth 2008). Despite this, clear juice is not a valuable source of bioactive substances (especially polyphenols) compared to cloudy product (Will et al. 2008). Cloudy apple juice contains natural colloidal suspensions (mainly pectins, proteins, and free amino acids), which have the stabilizing properties for colloidal systems (Siebert and Lynn 1997). In the manufacturing process there is no pulp enzymation, filtration or clarification because it leads to a reduction of serum viscosity and eliminates the cloudiness factors. The removal of pectin, polysaccharides, and phenolic compounds causes significant deterioration in the pro-healthy properties of the juice compared to fresh apple.

Many research suggest that a diet rich in apples may reduce the risk of diseases like overweight and obesity (Nagasako-Akazome et al. 2007, Akazome et al. 2010), cardiovascular diseases (Hyson et al. 2000) or cancer (Gerhacker 2008). The consumers become more aware of the diet effect on human health. It influences the fruit market situation including juices products. European Fruit Juice Association report points out that the consumption of juices from 'not from concentrates' juices (NFC) increased systematically from 1.498 to 1.767 million litres in years 2008-2012 and is still going up (AIJN 2013).

The problem of cloudy juices technology is to stabilize the cloudiness during storage and achieve a bright, natural color. In this respect, the quality of products depends strongly on the apple cultivars (Cliff and Dever 1990, Eisele and Drake 2005). Between them the distribution of phenolics (Wojdyło et al. 2008), extracts, pH, titratable acidity, ash or sugars content (Eisele and Drake 2005), as well as PPO (Kołodziejczyk et al. 2010), and PME activity (Wei et al. 2010, Gwanpua et al. 2014) are highly variable.

Apple juice is generally processed from fruits that are unsuitable for peeling, such as "eliminator" apples, smaller than $\sim 57 \mathrm{~mm}$ diameter, too small to peel etc. Some cultivars are grown specifically for processing. Despite this, most of the apples that are sold to the juice industry are salvaged fruit grown for the fresh market (Bates et al. 2001). The part of dessert apples (ca. 35\%) is used in the processing because of their low quality (Jabłońska-Ryś et al. 2014). However, for cloudy juices technology high quality fruits are required. The final product should be rich in ascorbic acid, polyphenols, and pectins. These compounds determine its biological value. 
Apples overproduction in Europe and a lack of significantly increasing fruit consumption requires a rational management of surpluses. According to market position of NFC juices, the continuation of the research regarding the use of different apple cultivars for processing is warranted. Development of apple juices assortment is observed also in the case of dessert cultivars. Cloudy products made e.g. of 'Pinova', 'Gala' or 'Golden Delicious' cvs. are available on the market. However, there are not many studies comprehensively describing the quality of single-cultivar cloudy juices by chemical and physical analysis. We still know too little about the effects of apples cultivars on PME activity in juices, although it is an important factor of consistency stability in fruit products.

Therefore, the aim of this study was to obtain a cloudy juice from selected dessert apple cultivars ('Alwa', 'Fiesta', 'Gloster', 'Golden Delicious', 'Mutsu', 'Pinova'), and the characteristics of these products in chemical (polyphenolic compounds content), enzymatic (PME residual activity), and physical aspect (color, viscosity, stability of turbidity).

\section{Materials and methods}

\section{Reagents and chemicals}

Quercetin glycosides (3-O-galactoside, 3-O-glucoside, 3-O-rhamnoside), cyanidin-3-O-galactoside, $p$-coumaric acid, cryptochlorogenic acid, (+)-catechin, (-)-epicatechin, proanthocyanidins $\mathrm{B} 1, \mathrm{~B} 2, \mathrm{C} 1$ and phloretin 2-Oglucoside were purchased from Extrasynthese (Lyon Nord, France). Chlorogenic acid were supplied by TRANS MIT $\mathrm{GmbH}$ (Giessen, Germany). Acetic acid, phloroglucinol, ascorbic acid, acetonitrile, apple pectin and methanol were purchased from Sigma - Aldrich (Steinheim, Germany).

\section{Apple cultivars for juice production}

Fruits of six dessert apple cultivars: 'Alwa', 'Fiesta', 'Gloster', 'Golden Delicious', 'Mutsu' and 'Pinova' (Malus domestica Borkh.) were collected in Experiment and Education Station of Department of Horticultre in Samotwor, Poland $\left(51^{\circ} 6^{\prime} 12^{\prime \prime} \mathrm{N}, 16^{\circ} 49^{\prime} 52^{\prime \prime} \mathrm{E}\right)$, belonging to Wroclaw University of Environmental and Life Sciences during 2013 season. Fully expanded, mature, with no visual damage fruits were stored at $4{ }^{\circ} \mathrm{C}$ in a cold room until analysis (ca. 7 days).

\section{Cloudy apple juice technology (laboratory scale)}

Washed and cut pieces of apples were disintegrated for $30 \mathrm{~s}$ in a Thermomix appliance (Vorwerk, Wuppertal, Germany) with addition of $10 \%$ solution of ascorbic acid (10 $\mathrm{g} \mathrm{kg}^{-1}$ of fruits). Apple pulp was pressed in a basket press (SSRE, Warsaw, Poland), at a piston thrust of $5000 \mathrm{~kg} \mathrm{~cm}^{-2}$ for $2 \mathrm{~min}$. The juice was pasteurized in Thermomix by heating to $100{ }^{\circ} \mathrm{C}$ during $5 \mathrm{~min}$, poured into colorless $80-\mathrm{ml} \mathrm{jars,} \mathrm{left} \mathrm{for} \mathrm{pasteurization} \mathrm{(10} \mathrm{min}$ ) and cooled to $20^{\circ} \mathrm{C}$. Three replicates of apple juice preparation were carried out. Juices were analyzed directly after processing.

\section{Determination of phenolic compounds UPLC coupled to PDA and FL detector}

The solvent for analysis of polyphenols was prepared as described previously by Wojdyło et al. (2014). Analysis was carried out on a UPLC system Acquity (Waters Corp., Milford, MA, USA) with a binary solvent manager, sample manager, PDA (model $\lambda$ e) and fluorescence detector (FL). For chromatographic data collection and chromatograms integration Empower 3 software was used. The UPLC analyses were performed on a BEH Shield C18 analytical column $(2.1 \mathrm{~mm} \times 50 \mathrm{~mm} \times 1.7 \mu \mathrm{m})$. The flow rate was $0.45 \mathrm{ml} \mathrm{min}^{-1}$. A partial loop injection mode with a needle overfill was set up, enabling $5 \mu$ injection volumes when a $10 \mu$ injection loop was used. Acetonitrile (100\%) was used as a strong wash solvent and acetonitrile in water $(10 \% \mathrm{v} / \mathrm{v})$ as a weak wash solvent.

$2 \mathrm{ml}$ of juices were centrifuged for $10 \mathrm{~min}$ at $15000 \mathrm{xg}$ at $4{ }^{\circ} \mathrm{C}$. The analytical column was kept at $30{ }^{\circ} \mathrm{C}$ by column oven, whereas the samples were kept at $4{ }^{\circ} \mathrm{C}$. The mobile phase was composed of solvent $A(4.5 \%$ formic acid) and solvent B (acetonitrile). Elution was as follows: $0-5 \mathrm{~min}$, linear gradient from $1 \%$ to $25 \%$ B; $5.0-6.5 \mathrm{~min}$, linear gradient from $25 \%$ to $100 \%$; $6.5-7.5 \mathrm{~min}$, column washing; and reconditioning for $0.5 \mathrm{~min}$. PDA spectra were measured over the wavelength range of $200-600 \mathrm{~nm}$ in steps of $2 \mathrm{~nm}$. The runs were monitored at the following wavelengths: flavan-3-ols at $280 \mathrm{~nm}$, hydroxycinnamates at $320 \mathrm{~nm}$, flavonol glycosides at $360 \mathrm{~nm}$, and anthocyanins at $520 \mathrm{~nm}$. Retention times $\left(t_{R}\right)$ and spectra were compared with those of pure standards. 
Calibration curves at concentrations ranging from 0.05 to $5 \mathrm{mg} \mathrm{ml}^{-1}\left(r^{2} \leq 0.9998\right)$ were made from $(+)$-catechin, (-)-epicatechin, procyanidins B1, B2, C1 chlorogenic acid, cryptochlorogenic acid, quercetin-3-O-glucoside, quercetin-3-O-galactoside, quercetin-3-O-rhamnoside, cyanidin-3-O-galactoside as standards. $p$-Coumaryloquinic acid was expressed as $p$-coumaric acid, and quercetin-3-O-xyloside and quercetin-3-O-arabinoside as quercetin-3-Ogalactoside. All samples were analyzed in triplicate. Results were expressed in $\mathrm{mg} \mathrm{l}^{-1}$.

\section{Analysis of proanthocyanidins by phloroglucinolysis}

Polymeric proanthocyanidins content were determined in freeze-dried apple juices (Alpha 1-4 LSC; Martin Christ $\mathrm{GmbH}$, Osterode am Harz, Germany) according to method described by Wojdyło et al. (2014). Parameters of freezedrying process: $18 \mathrm{~h}$ (time), 0.960 mbar (vacuum), $26^{\circ} \mathrm{C}$ (shelf temperature).

$0.5 \mathrm{~g}$ portion of lyophilized juice was placed into $2 \mathrm{ml}$ Eppendorf vials, mixed with $0.8 \mathrm{ml}$ of methanolic solution containing phloroglucinol $\left(75 \mathrm{~g} \mathrm{l}^{-1}\right)$ and ascorbic acid $\left(15 \mathrm{~g} \mathrm{l}^{-1}\right)$ and then with $0.4 \mathrm{ml}$ of methanol with $\mathrm{HCl}$ addition in dose $0.3 \mathrm{~mol} \mathrm{l}^{-1}$. The vials with reaction mixture were closed and incubated for $30 \mathrm{~min}$ at $50^{\circ} \mathrm{C}$ with all timevortexing by thermo shaker (TS-100, BIOSAN, Lithuania). The reaction was stopped by placing the vials in an ice bath with drawing $0.5 \mathrm{ml}$ of the reaction medium and diluting with $0.5 \mathrm{ml}$ of $0.2 \mathrm{~mol} \mathrm{I}^{-1}$ sodium acetate buffer. Next the vials were cooled in ice water and centrifuged immediately at $20000 \mathrm{xg}$ for $10 \mathrm{~min}$ at $4{ }^{\circ} \mathrm{C}$. Temperature in column oven and sample manager was $15^{\circ} \mathrm{C}$ and $4{ }^{\circ} \mathrm{C}$, respectively. The mobile phase was composed of solvent A (2.5\% acetic acid) and solvent B (acetonitrile). Elution was as follows: $0-0.6 \mathrm{~min}$, isocratic $2 \%$ B; $0.6-$ $2.17 \mathrm{~min}$, linear gradient from $2 \%$ to $3 \%$ B; $2.17-3.22 \mathrm{~min}$, linear gradient from 3\% to $10 \% \mathrm{~B} ; 3.22-5.00 \mathrm{~min}$, linear gradient from $10 \%$ to $15 \%$ B; 5.00-6.00 min, column washing and reconditioning for $1.50 \mathrm{~min}$. The fluorescence detection was recorded at an excitation wavelength of $278 \mathrm{~nm}$ and an emission wavelength of $360 \mathrm{~nm}$. The calibration curves, which were based on peak area, were established using (+)-catechin, (-)-epicatechin, and procyanidin B1 after phloroglucinol reaction as (+)-catechin and (-)-epicatechin-phloroglucinol adduct standards. The results were calculated as $\mathrm{mg} \mathrm{l}^{-1}$.

\section{Measurement of residual PME activity}

Residual PME activity was assayed according to the method of Askar and Treptow (1993). $20 \mathrm{ml}$ of juice was added to $40 \mathrm{ml}$ of $1 \%$ apple pectin solution in $2 \mathrm{~N} \mathrm{NaCl}$. The mixture of pectin and juice was adjusted to $\mathrm{pH} 7.0 \mathrm{with} 1 \mathrm{~N}$ $\mathrm{NaOH}$. When a stable $\mathrm{pH}$ was reached, $1 \mathrm{ml}$ of $0.05 \mathrm{~N} \mathrm{NaOH}$ was added and the time required for the $\mathrm{pH}$ to return to 7.0 was measured. Enzyme activity was calculated according to the formula:

UPE $\mathrm{ml}^{-1}=(\mathrm{ml} \mathrm{NaOH}) \times\left(\mathrm{NaOH}\right.$ normality) $\times 10^{3} /$ (minutes) $\times(\mathrm{ml}$ apple juice $)$

Values were converted to \% residual activity with respect to the non pasteurised control sample, which represents a PME activity of $100 \%$.

\section{Color measurement}

Color properties $\left(L^{*}, a^{*}, b^{*}\right)$ of juices were determined with Color Quest XE Hunter Lab colorimeter (Reston, USA). The samples were poured into a $2 \mathrm{~cm}$ cell. $L^{*}, a^{*}$ and $b^{*}$ values were determined using Illuminant D65 and $10^{\circ}$ observer angle.

\section{Viscosity measurement}

The viscosities were measured with a rotation viscometer MC1 (DV-II + PRO VISCOMETER, Brookfield, England) at $20^{\circ} \mathrm{C}$ and expressed in [mPas] unit.

\section{Turbidity measurement}

The turbidity were measured by a turbidimeter Turbiquant 3000T (Merck, Darmstadt, Germany) using $2.5 \mathrm{~cm}$ round cuvettes. Turbidity was expressed in nephelometric turbidity units (NTU). The stability of turbidity was deduced from the relative turbidity $(\% \mathrm{NTU})$ :

$\% \mathrm{NTU}=(\mathrm{Tc} / \mathrm{To}) \times 100$,

where $T o$ and $T c$ are the juice turbidities before and after centrifugation at $4200 \times \mathrm{g}$ for $15 \mathrm{~min}$ at $20^{\circ} \mathrm{C}$. 


\section{Statistical analysis}

All statistical analyses were performed with Statistica version 10.0 (StatSoft, Poland). One-way analysis of variance (ANOVA) by Duncan's test was used to compare the means. Differences were significant at $p<0.05$. Results were given as mean \pm standard deviation of three independent determinations.

\section{Results and discussion}

Flavan-3-ols

Flavan-3-ols were the major group of apple juices polyphenols (Table 1). Depending on the fruit cultivar, juices contained from 500.27 to $780.04 \mathrm{mg}$ of flavan-3-ols per litre ('Gloster' and 'Alwa' cv., respectively). The UPLC analysis indicated that the profile of these compounds included: monomers ( 2 compounds), dimers (2), trimers (1), as well as polymerized form with a high molecular weight. The polymeric proanthocyanidins were the main group of flavan-3-ols in cloudy apple juices. Their content - expressed in relation to adducts of phloroglucinol with (+)-catechin and (-)-epicatechin molecules - ranged between 350.13 and $529.73 \mathrm{mg} \mathrm{l}^{-1}$ ('Gloster' and 'Fiesta' juices, respectively; $p<0.05)$. These values corresponded to 51 and $69 \%$ of total quantitated polyphenols. According to Oszmiański et al. (2007), as well Kolniak-Ostek et al. (2013), the amounts of polymeric procyanidins differ significantly between apple cloudy juices. For example, the juice from 'Champion' cv. contained from 109 to $523.8 \mathrm{mg}$ of polymeric pranthocyanidins $\mathrm{I}^{-1}$, while in juice from 'Idared' cv. $208.1 \mathrm{mg} \mathrm{l}^{-1}$ was marked. These results are consistent with our data.

Table 1. Polyphenols content in cloudy juices from six apple cultivars $\left(\mathrm{mg} \mathrm{l}^{-1}\right)$

\begin{tabular}{|c|c|c|c|c|c|c|c|}
\hline $\begin{array}{c}\text { Group of } \\
\text { polyphenols }\end{array}$ & Compound & 'Alwa' & 'Fiesta' & ‘Gloster’ & $\begin{array}{c}\text { 'Golden } \\
\text { Delicious' }\end{array}$ & 'Mutsu' & 'Pinova' \\
\hline \multirow{13}{*}{ Flavan-3-ols } & \multirow[t]{2}{*}{ Procyanidin B1 } & 22.85 & 18.91 & 19.93 & 10.87 & 8.05 & 11.41 \\
\hline & & $\pm 0.40^{a}$ & $\pm 0.82^{c}$ & $\pm 0.30^{b}$ & $\pm 0.25^{\mathrm{e}}$ & $\pm 0.05^{f}$ & $\pm 0.50^{d}$ \\
\hline & \multirow[t]{2}{*}{$(+)$ - catechin } & 7.55 & 2.78 & 6.72 & 1.82 & 1.99 & 1.77 \\
\hline & & $\pm 0.30^{\mathrm{a}}$ & $\pm 0.10^{c}$ & $\pm 0.20^{\mathrm{b}}$ & $\pm 0.04^{e}$ & $\pm 0.00^{d}$ & $\pm 0.15^{f}$ \\
\hline & \multirow{2}{*}{ Procyanidin B2 } & 110.85 & $37.79 \pm$ & $60.58 \pm$ & $64.54 \pm$ & $46.77 \pm$ & $77.66 \pm$ \\
\hline & & $\pm 4.30^{\mathrm{a}}$ & $2.60^{f}$ & $3.01^{d}$ & $1.10^{c}$ & $1.80^{\mathrm{e}}$ & $1.20^{\mathrm{b}}$ \\
\hline & \multirow[t]{2}{*}{ (-)- epicatechin } & 88.42 & 25.67 & 42.83 & 33.26 & 32.28 & 54.57 \\
\hline & & $\pm 2.02^{\mathrm{a}}$ & $\pm 1.50^{f}$ & $\pm 3.30^{c}$ & $\pm 0.20^{d}$ & $\pm 0.12^{\mathrm{e}}$ & $\pm 0.50^{\mathrm{b}}$ \\
\hline & \multirow[t]{2}{*}{ Procyanidin C1 } & 38.35 & 13.81 & 20.08 & 21.42 & 12.88 & 27.68 \\
\hline & & $\pm 0.70^{a}$ & $\pm 0.10^{\mathrm{e}}$ & $\pm 0.02^{d}$ & $\pm 0.80^{c}$ & $\pm 0.00^{f}$ & $\pm 0.00^{b}$ \\
\hline & \multirow[t]{2}{*}{ Polimeric proanthocyanidins } & 512.02 & 529.73 & 350.13 & $488.60 \pm$ & 475.21 & 478.66 \\
\hline & & $\pm 2.00^{\mathrm{b}}$ & $\pm 1.40^{\mathrm{a}}$ & $\pm 1.50^{f}$ & $1.80^{\mathrm{C}}$ & $\pm 0.90^{\mathrm{e}}$ & $\pm 2.30^{d}$ \\
\hline & TOTAL & 780.04 & 628.68 & 500.27 & 620.51 & 577.18 & 651.75 \\
\hline \multirow{4}{*}{ Dihydrochalcones } & \multirow[t]{2}{*}{ Phloretin- 2'-O-xyloglucoside } & 2.15 & 1.74 & 4.43 & 4.73 & 3.32 & 2.53 \\
\hline & & $\pm 0.02^{e}$ & $\pm 0.00^{f}$ & $\pm 0.00^{b}$ & $\pm 0.05^{a}$ & $\pm 0.10^{c}$ & $\pm 0.08^{d}$ \\
\hline & \multirow[t]{2}{*}{ Phloretin- 2'-O-glucoside } & 38.03 & 15.40 & 8.71 & 13.17 & 6.65 & 13.03 \\
\hline & & $\pm 0.30^{\mathrm{a}}$ & $\pm 0.10^{b}$ & $\pm 0.00^{\mathrm{e}}$ & $\pm 0.20^{c}$ & $\pm 0.07^{f}$ & $\pm 0.10^{d}$ \\
\hline \multirow{8}{*}{$\begin{array}{l}\text { Hydroxycinnamic } \\
\text { acids }\end{array}$} & TOTAL & 40.18 & 17.14 & 13.15 & 17.90 & 9.98 & 15.56 \\
\hline & \multirow[t]{2}{*}{ Chlorogenic } & 152.18 & 114.45 & 160.88 & 135.32 & 138.91 & 145.64 \\
\hline & & $\pm 1.80^{\mathrm{b}}$ & $\pm 0.75^{f}$ & $\pm 1.20^{\mathrm{a}}$ & $\pm 2.50^{\mathrm{e}}$ & $\pm 0.60^{d}$ & $\pm 1.40^{c}$ \\
\hline & \multirow[t]{2}{*}{ Cryptochlorogenic } & 5.54 & $n f$ & 0.29 & 0.50 & nf & nf \\
\hline & & $\pm 0.10^{\mathrm{a}}$ & & $\pm 0.01^{c}$ & $\pm 0.00^{b}$ & & \\
\hline & \multirow[t]{2}{*}{ p-Coumaryloquinic } & 7.69 & 2.61 & 7.21 & 11.22 & 12.08 & 1.70 \\
\hline & & $\pm 0.05^{c}$ & $\pm 0.00^{e}$ & $\pm 0.00^{d}$ & $\pm 0.20^{\mathrm{b}}$ & $\pm 0.10^{\mathrm{a}}$ & $\pm 0.05^{f}$ \\
\hline & TOTAL & 165.42 & 117.06 & 168.38 & 147.04 & 150.98 & 147.34 \\
\hline \multirow{10}{*}{ Flavonols } & \multirow[t]{2}{*}{ Quercetin-3-O-galactoside } & 0.73 & 0.87 & 0.99 & 1.01 & 0.47 & 2.25 \\
\hline & & $\pm 0.01^{\mathrm{e}}$ & $\pm 0.00^{d}$ & $\pm 0.04^{c}$ & $\pm 0.00^{\mathrm{b}}$ & $\pm 0.00^{f}$ & $\pm 0.10 a$ \\
\hline & \multirow[t]{2}{*}{ Quercetin-3-O-glucoside } & 0.41 & $n f$ & 0.53 & 0.48 & 0.23 & 1.50 \\
\hline & & $\pm 0.00^{d}$ & $\mathrm{nI}$ & $\pm 0.00^{b}$ & $\pm 0.02^{c}$ & $\pm 0.00^{\mathrm{e}}$ & $\pm 0.00^{\mathrm{a}}$ \\
\hline & \multirow{2}{*}{ Quercetin-3-O-xyloside } & $n f$ & $n f$ & 0.67 & 0.60 & 0.44 & 0.92 \\
\hline & & $\mathrm{nt}$ & $\mathrm{n} \uparrow$ & $\pm 0.01^{b}$ & $\pm 0.00^{c}$ & $\pm 0.00^{d}$ & $\pm 0.02^{\mathrm{a}}$ \\
\hline & \multirow[t]{2}{*}{ Quercetin-3-O-arabinoside } & 0.63 & 0.34 & 0.94 & $n f$ & $n f$ & $n f$ \\
\hline & & $\pm 0.00^{b}$ & $\pm 0.00^{c}$ & $\pm 0.00^{\mathrm{a}}$ & & & \\
\hline & \multirow[t]{2}{*}{ Quercetin-3-O-rhamnoside } & 0.61 & 0.31 & 1.32 & 2.76 & 1.58 & 1.99 \\
\hline & & $\pm 0.01^{e}$ & $\pm 0.00^{f}$ & $\pm 0.00^{d}$ & $\pm 0.20^{\mathrm{a}}$ & $\pm 0.01^{c}$ & $\pm 0.00^{b}$ \\
\hline \multirow{4}{*}{ Anthocyanins } & TOTAL & 2.39 & 1.52 & 4.44 & 4.85 & 2.73 & 6.65 \\
\hline & \multirow[t]{2}{*}{ Cyanidin-3-O-galactoside } & 0.60 & 0.18 & 0.40 & & & 0.18 \\
\hline & & $\pm 0.00^{a}$ & $\pm 0.00^{c}$ & $\pm 0.01^{b}$ & $\mathrm{n} \dagger$ & $\mathrm{n} \dagger$ & $\pm 0.00^{c}$ \\
\hline & TOTAL & 0.60 & 0.18 & 0.40 & - & - & 0.18 \\
\hline
\end{tabular}


Among the flavan-3-ols, one trimeric compound was identified in apple juices. Trimers, called also ' $C$ ' - type proanthocyanidins, consist of three flavan-3-ol units linked by two C-4 $\rightarrow$ C- 8 interflavan bonds. The concentration of procyanidin $\mathrm{C} 1$ (epicatechin- $(4 \beta \rightarrow 8)$-epicatechin- $(4 \beta \rightarrow 8)$-epicatechin) was the highest in 'Alwa' juice (38.35 mg $\left.\mathrm{I}^{-1} ; p<0.05\right)$, followed by 'Pinova' (27.68) > 'Golden Delicious' (21.42) > 'Gloster' (20.08) > 'Fiesta' (13.81) > and 'Mutsu' (12.88 $\left.\mathrm{mg} \mathrm{l}^{-1}\right)$. The typical apple polyphenols are also the dimers of catechins. In cloudy juices procyanidin B2 (epicatechin- $(4 \beta \rightarrow 8)$-epicatechin) and B1 (epicatechin- $4 \beta \rightarrow 8)$-catechin) were found. The quantitative relations between flavanols in apples indicate the dominance of procyanidin of B2-type. Our results showed, that the content of this compound was 2-7 times higher than in the case of B1 - dimer. The richest source of dimeric procyanidin was cloudy juice from 'Alwa' cv. (110.85 and $22.85 \mathrm{mg} \mathrm{l}^{-1}$, respectively). Other samples contained significantly smaller amount of procyanidin B2 (from $37.79 \mathrm{mg} \mathrm{l}^{-1}$ in 'Fiesta' juice to $77.66 \mathrm{mg} \mathrm{l}^{-1}$ in 'Pinova' juice) and B1 (from 8.05 to $19.93 \mathrm{mg} \mathrm{l}^{-1}$ in 'Mutsu' and 'Gloster', respectively).

Taking into account the concentration of monomeric catechins, the similar regularity has been found. In 'Alwa' juice (the highest content of both monomers), the quantitative ratio of (-)-epicatechin to (+)-catechin was 12:1. In 'Pinova' juice, which was rich in (-)-epicatechin $\left(54.57 \mathrm{mg} \mathrm{l}^{-1}\right)$, but poor in (+)-catechin $\left(1.77 \mathrm{mg} \mathrm{l}^{-1}\right)$, the weight ratio was 31:1. Cloudy juice from 'Gloster' cv. contained 6 times more (-)-epicatechin than (+)-catechin (42.83 and $\left.6.72 \mathrm{mg} \mathrm{l}^{-1}\right)$. According to Panzella et al. (2013), apples contain considerably greater amounts of monomeric flavan-3-ols and the ratio of (+)-catechin to (-)-epicatechin range between 1:2 and 1:6. However, tata et al. (2009) described quite divergent relation. The concentration of catechins in a whole apple of 'Starking Delicious' cv. was the same for both of the compounds. Some cultivars, i.e. 'Granny Smith', 'Gloster' or 'Prima' were characterized by the higher content of (+)-catechin in relation to (-)-epicatechin. It indicates, that not only pre-harvest factors, i.e. cultivar variation, but also environmental factors (including temperature, sunshine radiation, and climatic conditions) may influence the level of phytochemicals in fruits (Tiwari and Cummins 2013).

\section{Dihydrochalcones}

The UPLC analysis showed, that in the juices 2 compounds from dihydrochalcones group: phloretin-2'-O-xyloglucoside and phloretin-2'-O-glucoside (phloridzin) were found. Their concentration was estimated between 9.98 and $40.18 \mathrm{mg} \mathrm{l}^{-1}(p<0.05)$. Considering the total content of polyphenols in juices, dihydrochalcones represented 1 to $4 \%$ of all identified antioxidants. Regardless of the cultivar, phloretin-2'-O-glucoside occurred in juices in higher concentration $(p<0.05)$, ranged between 6.65 and $38.03 \mathrm{mg} \mathrm{l}^{-1}$ (in 'Mutsu' and 'Alwa', respectively). Phloretin-2'$O$-xyloglucoside content was significantly lower. With the concentration between 1.74 and $4.73 \mathrm{mg} \mathrm{l}^{-1}$ (in 'Fiesta' and 'Golden Delicious', respectively), this compound made up 5 to $34 \%$ of total dihydrochalcones level. The highest contribution of phloretin-2'-O-xyloglucoside was marked in juice from 'Gloster' cv., the lowest- in 'Alwa' juice.

Dihydrochalcones are typically polyphenols group of apples and derived products. According to Gosch et al. (2010), ten phloretin derivatives were described from Malus species; however, phloridzin and phloretin-2'-O-xyloglucoside were mainly identified. Markowski et al. (2009) marked both of these dihydrochalcones in cloudy apple juices from French and Polish cultivars. The Authors indicated, that phloridzin dominates among dihydrochalcones with the content between $3.4 \mathrm{mg} \mathrm{l}^{-1}$ in 'Chanteline' and $165.7 \mathrm{mg} \mathrm{l}^{-1}$ in 'Judor' juices, while the concentration of $2^{\prime}$ - $O$-xylogalactoside ranged from 2.8 to $17.6 \mathrm{mg} \mathrm{l}^{-1}$ (in 'Chanteline' and 'Gold Millennium', respectively). These observations were were similar to those of Kolniak-Ostek et al. (2013), Oszmiański et al. (2008) or Schieber et al. (2001) and our results. However, some of the studies show, that the quantitative proportions between these compounds in apples and apple juices can be quite reversed. For example, in fruits of 'Fiesta' or 'Gala' cvs. (Ceyman et al. 2012) as well as pulp-enriched juices and cloudy juices produced from 'Topaz' and 'Boskoop' cv. (Will et al. 2008), higher content of phloretin-2'-O-xyloglucoside than phloridzin was found.

\section{Hydroxycinnamic aids}

Apples contain considerable amounts of hydroxycinnamic acid derivatives, which are mainly represented by chlorogenic acid (Soares et al. 2007). Chlorogenic acid is the ester product of (-)-quinic and 3,4-dihydroxycinnamic acids. Health-related properties of this compound were described in the literature, including the inhibition of carcinogenesis in the colon, the protection against oxidative stress in vivo or the reduction of cardiovascular disease risk by decreasing oxidation of LDL and total cholesterol (Cho et al. 2010). As our study demonstrated, in cloudy juices chlorogenic acid was more than $90 \%$ of hydroxycinnamic acids. Its content ranged from 114.45 to $160.88 \mathrm{mg} \mathrm{l}^{-1}$ (in 'Fiesta' and 'Gloster' juices, respectively; $p<0.05$ ). $p$-Coumaryloquinic acid occurred in tested products in significantly lower concentrations (between 1.70 and $12.08 \mathrm{mg} \mathrm{l}^{-1}$ in 'Pinova' and 'Mutsu' juices, respectively). 
Moreover, in 'Alwa', 'Gloster' and 'Golden Delicious' juices small amounts of cryptochlorogenic acid were also found (5.54; 0.29 and $\left.0.50 \mathrm{mg} \mathrm{l}^{-1} ; p<0.05\right)$. In most apple juices, the concentration of phenolic acids was higher than total content of mono-, di- and oligomeric flavan-3-ols. According to Kahle et al. (2005), hydroxycinnamic acids ranged from 57 to $68 \mathrm{mg} \mathrm{l}^{-1}$ in juices made from dessert apples and from 134 to $593 \mathrm{mg} \mathrm{l}^{-1}$ in cider apple juices. The polyphenolic profile of commercial cloudy apple juices was dominated by chlorogenic acid (53-217 $\left.\mathrm{mg} \mathrm{l}^{-1}\right)$, while total hydroxycinnamic acids amounts varied from 74 to $259 \mathrm{mgl}^{-1}$ (Kahle et al. 2005). In relation to flavanols content (measured as a sum of monomers and dimers) these values were much higher, which is consistent with our results.

\section{Flavonols}

Flavonols profile of juices consisted of 5 quercetin glycosides in a total concentration between 1.52 and $6.65 \mathrm{mg} \mathrm{l}^{-1}$ (in 'Fiesta' and 'Pinova', respectively; $p<0.05$ ). However, the qualitative and quantitative composition of these compounds was dependent on the apple cultivar. Quercetin-3-O-galactoside was the main flavonol marked in 'Alwa', 'Fiesta' and 'Pinova' juices $\left(0.73 ; 0.87 ; 2.25 \mathrm{mg} \mathrm{l}^{-1} ; p<0.05\right)$, while in 'Gloster', 'Golden Delicious' and 'Mutsu' quercetin-3-O-rhamnoside dominated $\left(1.32,2.76\right.$ and $1.58 \mathrm{mg} \mathrm{l}^{-1}$, respectively). Other flavonols compounds occurred in the products from certain cultivars. For example, 'Fiesta' juice did not contain quercetin-3-O-glucoside and 3-O-xyloside. In the juices from 'Golden Delicious', 'Mutsu' and 'Pinova' cv. quercetin -3-O-arabinoside was not found. Only in 'Gloster' cv. juice all of five quercetin glycosides were presented. However, it does not result in total flavonols concentration $\left(4.44 \mathrm{mg} \mathrm{l}^{-1}\right)$ which was significantly lower than in the case of 'Pinova' and 'Golden Delicious' cvs.

According to Kahle et al. (2005), total content of quercetin-glycosides in apple juices is strongly varied and ranges between 0.4 and $27 \mathrm{mg} \mathrm{l}^{-1}$ in fresh juice from dessert and ciders fruits and from 2 to $14 \mathrm{mg} \mathrm{l}^{-1}$ in commercial cloudy products. In the study of Olk et al. (2010), the concentration of flavonols in juices from cider apples ranged from 1.1 to $17.2 \mathrm{mg} \mathrm{l}^{-1}$. Juices contained five quercetin-glycosides, of which two (3-galactoside and 3-rhamnoside) was found in all of tested products. According to these Authors, the presence of another flavonols (3-glucoside, 3-xyloside and 3-arabinoside) was dependent on cultivar, which was also observed in our research.

\section{Anthocyanins}

Generally, one anthocyanin (cyanidin-3-O-galactoside) was present in apple juices but at different levels for different cultivars. The highest concentration of cyanidin-3-O-galactoside was characterized by 'Alwa' cv. juice $\left(0.60 \mathrm{mg} \mathrm{l}^{-1}\right)$, followed by 'Gloster' $\left(0.40 \mathrm{mg} \mathrm{l}^{-1}\right)>$ 'Fiesta' and 'Pinova' $\left(0,18 \mathrm{mg} \mathrm{l}^{-1} ; p>0.05\right)$.

Cyanidin-3-O-galactoside predominantly accumulated in the ripe apple fruit peel regardless of the time or cultivars (Liu et al. 2013). Up to now, about five anthocyanins occurring in apple are known. Cyanidin-3-O-galactoside was identified as the major pigment, accounting for $80 \%$ of total anthocyanins (Treutter 2001). The remaining anthocyanins include cyanidin-3-O-glucoside, 3-O-arabinoside, 3-O-rutinoside, and 3-O-xyloside (Ben-Yehudah et al. 2005). According to Awad et al. (2000), low levels of anthocyanins, moderate levels of quercetin 3-glycosides and relatively high levels of phloridzin, catechins and chlorogenic acid are found in the shaded skin of apple fruit and also in the skin from fruit borne in the inside of the canopy. It indicates that anthocyanins synthesis is a light-dependent process, while the synthesis of other phenolic metabolites is slightly if at all light-dependent.

\section{PME residual activity}

The results of measuring of the residual PME activity in the cloudy apple juices were indicated in Table 2 . The thermal treatment of juices (heating to $100^{\circ} \mathrm{C}$ during $5 \mathrm{~min}$, filling, $10 \mathrm{~min}$ of pasteurization), did not cause a complete inactivation of PME. However, the results of the analysis provided some information about the specific of apple juices in this aspect. At first, it is possible to create a preliminary classification of apple cultivars because of their enzymatic activity. On the other hand, we obtained an initial data on thermolability of enzyme in examined products.

PME activity was monitored twice, i.e. before and after juices pasteurization. Our study demonstrated that onecultivar cloudy juices were diverse in terms of enzymatic activity. In fresh pressed juices the PME activity was the highest in case of 'Mutsu' cv. (0.575 UPE ml-1) followed by 'Pinova' $(0.452)>$ 'Fiesta' $(0.381)>$ 'Alwa' $(0.332)>$ 'Gloster' (0.212) > and 'Golden Delicious' (0.200). 
Table 2. Residual PME activity (\%) of cloudy apple juices

\begin{tabular}{|c|c|c|c|}
\hline \multirow{2}{*}{ Juice } & \multicolumn{2}{|c|}{ PME activity (UPE $\mathrm{ml}^{-1}$ ) } & \multirow[b]{2}{*}{ Residual PME activity (\%) } \\
\hline & before pasteurization & after pasteurization & \\
\hline 'Alwa' & $0.332 \pm 0.008^{d}$ & $0.054 \pm 0.004^{e}$ & 16 \\
\hline 'Fiesta' & $0.381 \pm 0.012^{c}$ & $0.050 \pm 0.003^{f}$ & 13 \\
\hline 'Gloster' & $0.212 \pm 0.000^{\mathrm{e}}$ & $0.078 \pm 0.006^{b}$ & 37 \\
\hline 'Golden Delicious' & $0.200 \pm 0.007^{f}$ & $0.059 \pm 0.004^{d}$ & 30 \\
\hline 'Mutsu' & $0.575 \pm 0.004^{\mathrm{a}}$ & $0.100 \pm 0.000^{a}$ & 17 \\
\hline ‘Pinova' & $0.452 \pm 0.014^{b}$ & $0.062 \pm 0.002^{c}$ & 14 \\
\hline
\end{tabular}

Mean values within a column with different letters are significantly different at $p<0.05$.

Pasteurization reduced the enzyme activity. The influence of apple cultivar was important in this regard. Taking into account the \% of residual PME activity, the thermal treatment of apple juices was most effective in the case of 'Fiesta' and 'Pinova' cvs. ( $13 \%$ and $14 \%$ of the initial activity, respectively). The relatively high level of enzyme inactivation was also observed in 'Alwa' and 'Mutsu' juices (16 and 17\%, respectively). In juices from 'Golden Delicious' and 'Gloster' cv., the thermostability of PME was the strongest, what suggest the values of its residual activity (30 and $37 \%$, respectively). It is an interesting observation, because both of these juices were characterized by the lowest PME activity before thermal treatment.

PME catalyses the demethylesterification of galacturonic acid units of pectin, generating free carboxyl groups and releasing protons (Giovane et al. 2004). Once a critical degree of esterification is reached, divalent cations (mainly Ca) can cross-link free carboxylic groups belonging to adjacent pectin chains giving insoluble macropolymers that entrap other components of cloud. This process leads to clarification, which is undesirable in cloudy products. In the fruit juices industry, thermal treatment is the most common and least expensive process that has been used to solve the problem (Assis et al. 2001). According to Zhi et al. (2008), the residual activity of apple PME exhibits some fluctuations after mild heat at 35,45 , and $55^{\circ} \mathrm{C}$. ANOVA analysis indicated that the temperatures of 35 and $45^{\circ} \mathrm{C}$ have no significant effects on the residual activity of PME in comparison to the control sample. Although, it is reduced at $55^{\circ} \mathrm{C}$ as the treatment time increases (significant reduction obtained after $30 \mathrm{~min}$ ). The maximum reduction of enzyme activity was less than $20 \%$ for $60 \mathrm{~min}$. It suggests that apple PME is rather stable. In the study of Castaldo et al. (1997), PME activity of fruit purees samples was between $10^{-3}$ and $10^{-5} \mathrm{U} \mathrm{ml}^{-1}$. In particular, samples of apricot and apple purees were characterized by the highest residual PME activity. In case of apple purees (temperature of thermal treatment: $110-112{ }^{\circ} \mathrm{C}$, holding time: $1 \mathrm{~min} 30 \mathrm{~s}$ ) about $60 \%$ of examined samples showed higher activity than $1.0 \times 10^{-3} \mathrm{U} \mathrm{ml}^{-1}$, which is in line witch our research. However, the authors described that in the commercial apple nectars, PME activity was absent (Castaldo et al. 1997). Probably, the reason is that PME is not a unique enzyme but a mixture of several isoenzymes. For example, in citrus fruits 12 forms of PME were detected with very different heat stabilities (Versteeg 1979). Moreover, Carbonell et al. (2006) proved that the cultivar factor has a great influence on activity of this enzyme in orange juices and its thermostability (residual PME: from 4 to 34\%). This observation is also confirmed in our research regarding apple juices.

\section{Color}

The results of color measurement of apple juices in CIE $L^{*} a^{*} b^{*}$ system were presented in Table 3 . The lowest values of $L^{*}$ (lightness; 44.89) and $b^{*}$ parameters (yellow color; 0.01 ), as well the largest share of red color $a^{*}(2.7)$, was observed in 'Alwa' cv. juice. These observations are closely related to the profile and content of polyphenolic compounds in this product. As the UPLC analysis showed, 'Alwa' juice had the highest anthocyanin content of all tested samples. Generally, the lower levels of cyanidin-3-O-galactoside made color of juices lighter, and the share of the $a^{*}$ parameter shifted towards the negative values, indicating the dominance of the green color. Thus, in 'Gloster', 'Fiesta' and 'Pinova' juices, $a^{*}$ value decreased gradually with decreasing content of anthocyanins and amounted to $-0.23,-2.49$, and -2.65 ( $p<0.05)$. In 'Golden Delicious' and 'Mutsu' juices, which did not contain anthocyanins, the share of green $\left(-a^{*}\right)$ was the largest $(-2.84$ and $-2.85 ; p>0.05)$. The results of color components measurement indicated that in all of juices (excluding 'Alwa') yellow color $\left(b^{*}\right)$ was strongly constituted. The highest values of this parameter were determined in 'Golden Delicious' juice (23.16), followed by 'Mutsu' (18.77) > 'Fiesta' (15.08) > 'Gloster' (12.59) > and 'Pinova' (12.41). The increasing participation of $b^{*}$ accompanied by a parallel increase in the brightness of the samples. Therefore, the highest value of the $L^{*}$ component was characterized 'Golden Delicious' juice (55.18). 
Table 3. The effect of apple cultivar on physical properties of cloudy juices

\begin{tabular}{|c|c|c|c|c|c|c|c|}
\hline \multicolumn{2}{|c|}{ Quality parameters } & \multicolumn{6}{|c|}{ Juice } \\
\hline & $L^{\prime}$ & $\begin{array}{c}\text { 'Alwa' } \\
44.89 \pm 0.80^{f}\end{array}$ & $\begin{array}{c}\text { 'Fiesta' } \\
51.2 \pm 1.00^{c}\end{array}$ & $\begin{array}{c}\text { 'Gloster' } \\
49.28 \pm 0.50^{d}\end{array}$ & $\begin{array}{c}\text { 'Golden Delicious' } \\
55.18 \pm 1.40^{\mathrm{a}}\end{array}$ & $\begin{array}{c}\text { 'Mutsu' } \\
54.36 \pm 0.30^{\mathrm{b}}\end{array}$ & $\begin{array}{c}\text { 'Pinova' } \\
45.85 \pm 0.60 \text { e }\end{array}$ \\
\hline \multirow[t]{2}{*}{ Color } & $a^{*}$ & $2.7 \pm 0.00^{\mathrm{a}}$ & $-2.49 \pm 0.20^{c}$ & $-0.23 \pm 0.01^{b}$ & $-2.84 \pm 0.00^{\mathrm{e}}$ & $-2.85 \pm 0.01^{\mathrm{e}}$ & $-2.65 \pm 0.00^{d}$ \\
\hline & $b^{*}$ & $0.01 \pm 0.00^{f}$ & $15.08 \pm 0.10^{c}$ & $12.59 \pm 0.20^{d}$ & $23.16 \pm 0.00^{\mathrm{a}}$ & $18.77 \pm 0.30^{\mathrm{b}}$ & $12.41 \pm 0.10^{\mathrm{e}}$ \\
\hline \multicolumn{2}{|c|}{ Viscosity [mPas] } & $5.40 \pm 0.00^{d}$ & $6.00 \pm 0.00^{c}$ & $5.40 \pm 0.00^{d}$ & $9.60 \pm 0.50^{\mathrm{a}}$ & $7.20 \pm 0.00^{b}$ & $2.40 \pm 0.00^{\mathrm{e}}$ \\
\hline \multicolumn{2}{|c|}{$\begin{array}{l}\text { Stability of turbidity } \\
\text { [\%] }\end{array}$} & $28.18 \pm 1.20^{d}$ & $27.51 \pm 0.80^{\mathrm{e}}$ & $35.75 \pm 2.00^{\mathrm{a}}$ & $34.43 \pm 1.40^{\mathrm{b}}$ & $33.07 \pm 0.50^{c}$ & $18.07 \pm 1.00^{f}$ \\
\hline
\end{tabular}

Mean values within a row with different letters are significantly different at $p<0.0$

\section{Viscosity and turbidity stability}

In cloudy juices the viscosity was also determined. Statistical analysis showed significant $(p<0.05)$ differences in apple juices in this regard. The highest viscosity was characterized by 'Golden Delicious' juice ( $9.60 \mathrm{mPas}$ ), followed by 'Mutsu' (7.20) > 'Fiesta '(6.00) > 'Alwa', 'Gloster' (5.40; $p<0.05)>$ and 'Pinova' (2.40). According to Will et al. (2008), the viscosities of the cloudy apple juices were between $1.74 \mathrm{mPas}$ ('Topaz') and $2.15 \mathrm{mPas}$ ('Boskoop'), whereas in the purees higher values were marked, i.e. 95 and 134 mPas, respectively. Genovese and Lozano (2006) pointed out, that the soluble solids concentration has an important effect on values of this parameter in cloudy apple juice from 'Granny Smith' cv. (e.g. $1.709 \mathrm{mPas}$ by $10^{\circ} \mathrm{Brix}$ and $3.647 \mathrm{mPas}$ by $20^{\circ} \mathrm{Brix}$ ).

Pectins concentration create the viscosity of fruit products and thus also consistency. They are a family of complex hetero-polysaccharides that mainly contain esterified 1,4-link $\alpha$-D-galactosyluronic residues, with the carboxyl groups (C-6) methylesterified to variable extents, which form a pectin network that physically entraps other particles (Rao \& Cooley 1992). Therefore, for production of cloudy apple juices, an enzyme application cannot be performed, as viscosity and turbidity stability would be degraded by pectin hydrolysis (Toepfl \& Heinz 2011). Stability of turbidity is generally one of the most important parameters reflecting the quality of cloudy products. According to Dietrich et al. (1996), in naturally cloudy juices \%NTU should be higher than $50 \%$ at a minimum stable turbidity range between 250 and 300 NTU. Our research showed, that in the examined juices from six apple cultivars the turbidity stability was much less than the optimum value. In the case of 'Gloster', 'Golden Delicioius' and 'Mutsu' juices the share of stable NTU exceeded only 30\%. In 'Alwa' and 'Fiesta' it was ca. 28\%, while in 'Pinova' juice the turbidity was highly unstable (18\%). It can be observed that results of measuring the viscosity in juices were not always closely related to NTU analysis. For example, 'Alwa' and 'Gloster' juices, despite identical viscosity values (5.40 mPas), were significantly varied in terms of content of a stable turbidity ( 28.18 and $35.75 \%$, respectively; $p<0.05)$. However, the correlation between both of these physical parameters is indisputable.

Dever et al. (1991) suggest that the main factors, which determine a stable turbidity and their characteristic in juices, are fruit maturity and storage conditions. The turbidity of juice consists of particles of different sizes. Small sedimentation rate shows particles with diameters ranging from 1 to $100 \mu \mathrm{m}$, e.g. the cell aggregates, single cells, cell wall fragments or starch molecules. Previous research proved strong sedimentation tendency of particles which size exceeds $1 \mathrm{~mm}$, i.e. fragments of seeds, skins, pulp and other parts (Markowski 1998).

\section{Conclusions}

The quality of cloudy juices depends on many conditions. There is no only about physical traits like color and turbidity. The contest of polyphenols is also important-especially for functional food designers. In consequence, the selection (cultivar selection, especially) of raw materials for food processing impacts on the final product. Referring to our research- juices made of several apple's cultivars exhibits different quality parameters. So some cultivars are more useable for industry than others. Due to the diversity of fruit cultivars, cloudy apple juices are characterized by high content of polyphenolic compounds. Dessert apples such as 'Alwa', 'Golden Delicious' and 'Pinova' are particularly valuable in this regard. The additional advantage of examined products includes also an attractive color (confirmed by the analysis of $L^{*} a^{*} b^{*}$ parameters) and relatively high thermolability of PME- enzyme. The mainly quality problem was low stability of turbidity, which may cause destabilization of consistency during juices storage. 


\section{Acknowledgements}

This work was supported by the National Sciences Center, Poland (NCN) under grant No. DEC-2013/09/N/NZ9/00222.

\section{References}

AIJN 2013. Liquid Fruit Market Report. http://www.aijn.org/pages/main/facts-figures.html.

Akazome, Y., Kametani, N., Kanda, T., Shimasaki, H. \& Kobayashi S. 2010. Evaluation of safety of excessive intake and efficacy of long-term intake of beverages containing apple polyphenols. Journal of Oleo Science 6: 321-338.

Askar, A. \& Treptow H. 1993. Determination of pectinesterase activity. In: Quality assurance in tropical fruit processing. Berlin, Germany: Springer-Verlag. p. 41-45.

Assis, S.A., Lima, D.C. \& Oliviera O.M.M.F. 2001. Activity of pectinmethylesterase, pectin content and vitamin C in acerola fruit at various stages of fruit development. Food Chemistry 74: 133-137.

Awad, M.A., de Jager, A. \& van Westing, L.M. 2000. Flavonoid and chlorogenic acid levels in apple fruit: characterisation of variation. Scientia Horticulturae 83: 249-263.

Bates, R.P., Morris, J.R. \& Crandall, P.G. 2001. Principles and practices of small- and medium- scale fruit juice processing. FAO Agricultural Services Bulletin 146: 1-219.

Ben-Yehudah, G., Korchinsky, R., Redel, G., Ovadya, R., Oren-Shamir, M. \& Cohen, Y. 2005. Color accumulation patterns and the anthocyanin biosynthetic pathway in 'Red Delicious' apple variants. The Journal of Horticultural Science and Biotechnology 80: 187-192.

Carbonell, J.V., Contreras, P., Carbonell, L. \& Navarro, J.L. 2006. Pectin methylesterase activity in juices from mandarins, oranges and hybrids. European Food Research and Technology 222: 83-87.

Castaldo, D., Laratta, B., Loiudice, R., Giovane, A., Quagliuolo, L. \& Servillo, L. 1997. Presence of Residual Pectin Methylesterase Activity in Thermally Stabilized Industrial Fruit Preparations. LWT - Food Science and Technology 30: 479-484.

Ceymann, M., Arrigonia, E., Schärera, H., Nisinga, A. \& Hurrell, R.F. 2012. Identification of apples rich in health-promoting flavan3-ols and phenolic acids by measuring the polyphenol profile. Journal of Food Composition and Analysis 26: 128-135.

Cho, A.S., Jeon, S.-M., Kim, M.-J., Yeo, J., Seo, K.-I., Choi, M.-S. \& Lee, M.-K. 2010. Chlorogenic acid exhibits anti-obesity property and improves lipid metabolism in high-fat diet-induced-obese mice. Food and Chemical Toxicology 48: 937-943.

Cliff, M. \& Dever, M. 1990. Characterisation of varietal apple juices. Canadian Institute of Food Science and Technology Journal 23: $217-222$.

Dever, M.C., Cliff, M. \& Vento L. 1991. Effect of apple storage on the quality of nonoxidative juice. Canadian Institute of Food Science and Technology Journal 24: 252-258.

Dietrich, H., Gierschner, K., Pecoroni, S., Zimmer E. \& Will F. 1996. Neuere Erkenntnisse zu dem Phanomen der Trubungsstabilitat - Erste Ergebnisse aus einem Forschungsprogramm. Flussiges Obst 63: 7-10. (In German).

Eisele, T. \& Drake S.R. 2005. The partial compositional characteristics of apple juice from 175 apple varieties. Journal of Food Composition and Analysis 18: 213-221.

Genovese, D.B. \& Lozano, J.E. 2006. Contribution of colloidal forces to the viscosity and stability of cloudy apple juice. Food Hydrocolloid 20: 767-773.

Gerhacker, C. 2008. Cancer chemopreventive potential of apples, apple juice, and apple components. Planta Medica 74: 1608-1624.

Giovane, A., Servillo, L., Balestrieri, C., Raiola, A., D’Avino, R., Tamburrini, M., Ciardiello, M.A. \& Camardella, L. 2004. Pectin methylesterase inhibitor. Biochimica et Biophysica Acta 1696: 245-252.

Gosch, C., Halbwirth, H. \& Stich, K. 2010. Phloridzin: Biosynthesis, distribution and physiological relevance in plants. Phytochemistry 71: 838-843.

Gwanpua, S.G., Van Buggenhout, S., Verlinden, B.E., Christiaens, S., Shpigelman, A., Vicent, V., Kermani, Z.J., Nicolai, B.M., Hendrickx, M. \& Geeraerd, A. 2014. Pectin modifications and the role of pectin degrading enzymes during postharvest softening of Jonagold apples. Food Chemistry 158: 283-291.

Hyson, D., Studebaker-Hallman, D., Davis, P.A. \& Gershwin, M.E. 2000. Apple juice consumption reduces plasma low-density lipoprotein oxidation in healthy men and women. Journal of Medicinal Food 3: 159-166.

Jabłońska-Ryś, E., Gustaw, W. \& Latoch, A. 2014. Assessing technological usefulness of selected apples varieties in terms of browning potential. Żywność. Nauka. Technologia. Jakość 1: 114-123. (In Polish).

Kahle, K., Kraus, M. \& Richling, E. 2005. Polyphenol profiles of apple juices. Molecular Nutrition \& Food Research 49: 797-806. Kay-Shuttleworth, R. 2008. The World and Europe Fruit Juice Industry in Data. AIJN 50th Anniversary Symposium, Brussels, Belgium.

Kolniak-Ostek, J., Oszmiański, J. \& Wojdyło, A. 2013. Effect of apple leaves addition on physicochemical properties of cloudy beverages. Industrial Crops and Products 44: 413-420.

Kołodziejczyk, K., Milala, J., Sójka, M., Kosmala, M. \& Markowski, J. 2010. Polyphenol oxidase activity in selected apple cultivars. Journal of Fruit and Ornamental Plant Research 18: 51-61.

Łata, B., Trampczyńska, A. \& Paczesna, J. 2009. Cultivar variation in apple peel and whole fruit phenolic composition. Scientia Horticulturae 121: 176-181. 
Liu, Y., Che, F., Wang, L., Meng, R., Zhang, X. \& Zhao, Z. 2013. Fruit coloration and anthocyanin biosynthesis after bag removal in non-red and red apples (Malus $\times$ domestica Borkh.). Molecules 18: 1549-1563.

Markowski, J. 1998. Some factors affecting quality and stability of cloudy apple juice. Fruit Processing 7: 277-282.

Markowski, J., Baron, M., Mieszczakowska, M. \& Płocharski, W. 2009. Chemical composition of French and Polish cloud apple juices. The Journal of Horticultural Science and Biotechnology: ISAFRUIT Special Issue. p. 68-72.

Nagasako-Akazome, Y., Kanda, T., Ohtake, Y., Shimasaki, H. \& Kobayashi, T. 2007. Apple polyphenols influence cholesterol metabolism in healthy subjects with relatively high body mass index. Journal of Oleo Science 56: 417-428.

Olk, M., Dietrich, H., Ludwig, M. \& Will, F. 2010. Impact of variety and vintage on the polyphenols composition of apple juices. Mitteilungen Klosterneuburg 60: 287-296.

Oszmiański, J., Wolniak, M., Wojdyło, A. \& Wawer, I. 2007. Comparative study of polyphenolic content and antiradical activity of cloudy and clear apple juices. Journal of the Science of Food and Agriculture 87: 573-579.

Oszmiański, J., Wolniak, M., Wojdyło, A. \& Wawer, I. 2008. Influence of apple puree preparation and storage on polyphenol contents and antioxidant activity. Food Chemistry 107: 1473-1484.

Panzella, L., Petriccione, M., Rega, P., Scortichini, M. \& Napolitano, A. 2013. A reappraisal of traditional apple cultivars from Southern Italy as a rich source of phenols with superior antioxidant activity. Food Chemistry 140: 672-679.

Rao, M.A. \& Cooley, H.J. 1992. Rheology of tomato pastes in steady dynamic shear. Journal of Texture Studies 12: 521-538.

Schieber, A., Keller, P. \& Carle, R. 2001. Determination of phenolic acids and flavonoids of apple and pear by high-performance liquid chromatography. Journal of Chromatography A 910: 265-273.

Siebert, K.J. \& Lynn, P.Y. 1997. Haze-active protein and polyphenols in apple juice assessed by turbidimetry. Journal of Food Science 62: 79-84.

Soares, M.C., Ribeiro, E.T., Kuskoski, E.M., Gonzaga, L.V., Lima, A., Filho, J.M. \& Fett, R. 2007. Composition of phenolic acids content in apple (Malus sp) pomace. Semina: Ciências Agrárias, Londrina 29: 339-348.

Tiwari, U. \& Cummins, E. 2013. Factors influencing levels of phytochemicals in selected fruit and vegetables during pre- and post-harvest food processing operations. Food Research International 50: 497-506.

Toepfl, S. \& Heinz, V. 2011. Pulsed Electric Field Assisted Exctraction- A Case Study . In: Zhang, H.Q., Barbosa-Cánovas, G.V., Balasubramaniam, V.M., Dunne, C.P., Farkas, D.F. \& Yuan, J.T.C. (eds.). Nonthermal processing technologies for food. Section II Electromagnetic processes. UK, Blackwell Publishing Ltd. and Institute of Food Technologist. p. 190-200.

Treutter, D. 2001. Biosynthesis of phenolic compounds and its regulation in apple. Plant Growth Regulation 34: 71-89.

Versteeg, C. 1979. Agricultural-Research-Reports. Wageningen Agriculture University, Wageningen, The Netherlands. 892: 109.

Wei, J., Ma, F., Shi, S., Qi, X., Zhu, G. \& Yuan, J. 2010. Changes and postharvest regulation of activity and gene expression of enzymes related to cell wall degradation in ripening apple fruit. Postharvest Biology and Technology 56: 147-154.

Will, F., Roth, M,, Olk, M., Ludwig, M. \& Dietrich, H. 2008. Processing and analytical characterization of pulp-enriched cloudy apple juices. LWT - Food Science and Technology 41: 2057-2063.

Wojdyło, A., Oszmiański, J. \& Laskowski, P. 2008. Polyphenolic Compounds and Antioxidant Activity of New and Old Apple Varieties. Journal of Agricultural and Food Chemistry 56: 6520-6530.

Wojdyło, A., Teleszko, M. \& Oszmiański, J. 2014. Antioxidant property and storage stability of quince juice phenolic compounds. Food Chemistry 152: 261-270.

Zhi, X., Zhang, Y., Hu, X., Wu, J. \& Liao, X. 2008. Inactivation of Apple Pectin Methylesterase Induced by Dense Phase Carbon Dioxide. Journal of Agricultural and Food Chemistry 56: 5394-5400. 